\title{
Risk factors for incident shoulder soft tissue rheumatic disorders: a population-based case-control study in Lebanon
}

\author{
Mohammad Godah ${ }^{1,2}$, Monique Chaaya ${ }^{1}$, Zeinab Slim ${ }^{3,4}$ and Imad Uthman ${ }^{5}$
}

${ }^{1}$ Department of Epidemiology and Population Health, Faculty of Health Sciences, American University of Beirut, Beirut, Lebanon; ${ }^{2}$ Clinical Research Institute, American University of Beirut, Beirut, Lebanon; ${ }^{3}$ Department of Epidemiology, Biostatistics and Occupational Health; ${ }^{4}$ Division of Clinical Epidemiology, Research Institute of the McGill University Health Centre, McGill University, Montreal, Quebec, Canada. ${ }^{5}$ Division of Rheumatology, Department of Internal Medicine, American University of Beirut Medical Center, American University of Beirut, Beirut, Lebanon (Correspondence to: Monique Chaaya: mchaaya@aub.edu.lb)

\begin{abstract}
Background: Soft tissue rheumatic disorders (STRDs) are very common and impact enormously general population, working groups and physiotherapist practices. However, they do not have neither a clear case definition nor objective tests to be accurately diagnosed rendering them neglected with poorly-estimated burden. Shoulder is one of the most frequent sites for STRDs.
\end{abstract}

Aim: The aim of this study was to identify risk factors for shoulder STRDs among Lebanese adults aged $\geq 15$ years.

Methods: A case-control study was designed based on data from the Community Oriented Program for Control of Rheumatic Diseases (COPCORD) study conducted in Lebanon in 2009. Cases were defined as those who recently suffered from shoulder pain, tenderness or stiffness with duration not exceeding 12 months (52 cases). These were frequency-matched by age and gender with 208 controls who never experienced any musculoskeletal pain.

Results: Area of residence, physical activity, family history and stress-induced sleep difficulty were significantly associated with shoulder STRDs after adjusting for cigarette smoking, job nature and family monthly income.

Conclusion: Factors associated with shoulder STRD among the Lebanese population include geographical location, psychosocial factors, physical activity and familial predisposition. Further longitudinal studies are needed to establish a temporal sequence and explore other potential determinants, especially among the working population.

Keywords: Epidemiology; soft tissue rheumatic disorders (STRDs); soft tissue rheumatism (STR); shoulder pain; musculoskeletal (MSK) disorders

Citation: Godah M; Chaaya M; Slim Z; Uthman I. Risk factors for incident shoulder soft tissue rheumatic disorders: a population-based case-control study in Lebanon. East Mediterr Health J. 2018;24(4):393-400. https://doi.org/10.26719/2018.24.4.393

Received: 26/02/16; accepted: 15/06/17

Copyright @ World Health Organization (WHO) 2018. Some rights reserved. This work is available under the CC BY-NC-SA 3.0 IGO license (https:// creativecommons.org/licenses/by-nc-sa/3.0/igo).

\section{Introduction}

Rheumatic and musculoskeletal diseases constitute a major public health problem due to their exceptionally high prevalence and burden (1). They are a major cause of disability, responsible for $21.3 \%$ of the total years lived with disability in the world accounting for $6.7 \%$ of the total global disability-adjusted life years (1).

Soft tissue rheumatic disorders, also called soft tissue rheumatism (STR), are a constellation of syndromes that involve tissues around joints, e.g. muscles, tendons and ligaments, causing pain and movement limitation (2). Contrary to the belief that STRs are rare, benign and self-limiting, there is sufficient evidence that STRs are common, can become chronic (duration $\geq 3$ months) and are resource-consuming, especially in industrialized countries $(3,4)$. Clinically, STRs have vague case definitions, which poses a dilemma for primary health care physicians and general practitioners. They have unclear pathogenesis and are not precisely diagnosed due to the unavailability of specific lab and radiology tests. So, physicians rely solely on history and clinical examination $(2,5)$.
Most of the studies assessing the magnitude of STRs have been cross-sectional, ignoring the natural course of STRs, i.e. recurrent and episodic (6). This intermittency in the pattern of STRs constitutes a huge epidemiological barrier for the precise measurement of their incidence (3).

Studies have shown a higher prevalence of pain in the shoulder $(18-20 \%)$ compared to other parts of the body (3). In a national survey conducted in Lebanon in 2009 on musculoskeletal disorders, the shoulder was the most affected site with $14.3 \%$ total prevalence (7). Shoulder pain comes second to low back pain as the most common disorder in middle-aged adults (8). Shoulder STRs enormously impact the general population, especially the work force. A recent study showed high prevalence of anxiety, depression and sleep disturbances in patients with chronic shoulder pain (9). They are direct causes of long-term sick leave and low health status among workers (10). In Sweden, a study showed that the cost of sick leave contributed to $84 \%$ of the total costs and the mean annual total cost was €4139 per shoulder pain patient (11).

Many risk factors are associated with shoulder STRs and these are categorized into 3 main groups; individual, occupational and psychosocial $(3,10)$. Shoulder 
pain and STRs tend to become more prevalent with age $(3,10)$; females are over-represented over males in all musculoskeletal disorders and at each anatomic site $(3,12,13)$. Obesity is reported to be associated with increased pain in neck, shoulder and upper limb (14-16). Likewise, poor dietary habits could result in poor nutritional status and weaker bones (17). There is an association between smoking and chronic shoulder pain (15,18-21). Workplace exposures e.g. to heavy lifting, faulty body positions and vigorous labour, increase the risk of shoulder STRs (22). Work stress, e.g. high demand, may eventually lead to musculoskeletal pain that turns chronic and causes much distress, sleep difficulty and depression $(3,9,22)$.

Lebanon has a fairly small number of rheumatologists $(\mathrm{n}=50)$. This increases the workload on the primary health care physicians to accommodate the huge burden of musculoskeletal conditions. The situation is exacerbated by the lack of, or inadequate, undergraduate rheumatology teaching of primary health care professionals.

The objective of this study was to investigate various factors associated with shoulder STRs affecting adult Lebanese aged $\geq 15$ years using the Community Oriented Program for Control of Rheumatic Diseases (COPCORD) study data.

\section{Methods}

\section{Study design}

A case-control design was adopted. The study is based on a secondary analysis of de-identified data from the national COPCORD study conducted in Lebanon in 2009 (7) and approved by the Institutional Review Board of the American University of Beirut. This COPCORD study investigated the prevalence of various rheumatic disorders in Lebanon using a multistage probability sample of households. The first stage of the study was to visit the sampled households and conduct the COPCORD core questionnaire by trained interviewers with 1 randomly selected member of the household who was aged $\geq 15$ years. In the second stage, rheumatology fellows examined participants who responded positively to the question: "Have you suffered from pain/swelling/stiffness in the joints or musculoskeletal soft tissues within the last 7 days, or some time in the past, with pain intensity on the visual analogue scale $\geq 4$ ". If laboratory tests were required, a third visit was organized to withdraw the necessary blood samples by a trained registered nurse (7).

\section{Selection of cases and controls}

We selected 52 incident cases who reported current shoulder pain, tenderness or stiffness with duration not exceeding 12 months. Using frequency matching for age and gender, we randomly selected 4 population-based controls per case (total 208) from the data. Sample size calculation was based on maintaining 0.8 power of detecting a minimum adjusted odds ratios (OR) of 2 . We defined controls as participants who had never suffered from musculoskeletal pain. The final sample that we analysed for this study included 260 COPCORD participants
(52 incident cases plus 208 frequency matched controls) (Figure 1).

\section{Measures}

We examined the following variables in our case-control study: geographical location assessed by place of residence (Beirut, Mount Lebanon, North, Bekaa and South governorates); socioeconomic status assessed by monthly income in Lebanese lira (LL): low < LL 500 o00 ( $\approx$ US\$ 334); medium LL 500 ooo to LL $\leq 1$ million ( $\approx$ US\$ 667); high > 1 million LL; and education level (low: elementary school or below; medium: intermediate or high school; high: university or technical college); constitutional profile/obesity status [body mass index (BMI) normal: $\leq 24.9$ $\mathrm{kg} / \mathrm{m} 2$; overweight: $25.0-29.9 \mathrm{~kg} / \mathrm{m} 2$; obese: $\geq 30 \mathrm{~kg} / \mathrm{m} 2$ ], behavioural and psychosocial patterns [cigarette and waterpipe (hookah) smoking, alcohol consumption, physical activity, stress-induced sleep difficulty and self-evaluation of general health status compared to others], family history of musculoskeletal disorders and nature of job (administrative work, manual and agriculture/military).

\section{Statistical analysis}

The distribution of cases and controls according to selected variables was compared and chi-squared tests were done to check for statistical differences. At the bivariate level of analysis, associations with $P$-value $\leq 0.20$ were considered for inclusion in the multiple logistic regression model.

The final regression model included only variables that showed statistical significance (at the 5\% level). Both crude and adjusted OR were recorded along with the corresponding 95\% confidence intervals (CI) and 2-sided P-values. We used the log likelihood ratio test to assess goodness of fit and to choose the appropriate model. Age and sex were included in the final model.

Statistical analyses were performed using SPSS, version 21 and STATA, version 13 statistical packages.

\section{Results}

Table 1 shows the baseline characteristics of the 52 shoulder STR cases. Most are female (67.31\%). Just over 50\% reported having pain $\geq 6$ on the visual analog scale with mean 6.5 (SD 1.94; range 0-10). Half reported having difficulty in doing their daily activities; the most reported difficulties were bending down to pick up clothes (34.6\%), lifting a water barrel (32.7\%), washing and drying the entire body $(23.1 \%)$ and dressing (23.1\%). More than half (57.7\%) reported that they received treatment for their shoulder problem: $76.7 \%$ received the treatment from a doctor, mainly rheumatologists $(47.83 \%)$ and general practitioners (30.43\%). Out of the $47.5 \%$ who were working, 7.5\% reported being absent from work in the past 6 months because of the shoulder pain.

Table 2 shows the bivariate analysis of the estimated differences between cases and controls for the associated variables. Being physically inactive $(\mathrm{OR}=3.48,95 \% \mathrm{CI}$ : 1.54-7.87), having a positive family history for shoulder musculoskeletal disorders $(\mathrm{OR}=6.23$, 95\% CI: 2.95- 
Figure 1 Flowchart showing study selection process [soft tissue rheumatic disorders (STRs) defined as "constellation of syndromes that involve tissues around joints e.g. muscles, tendons, ligaments with movement limitation"]

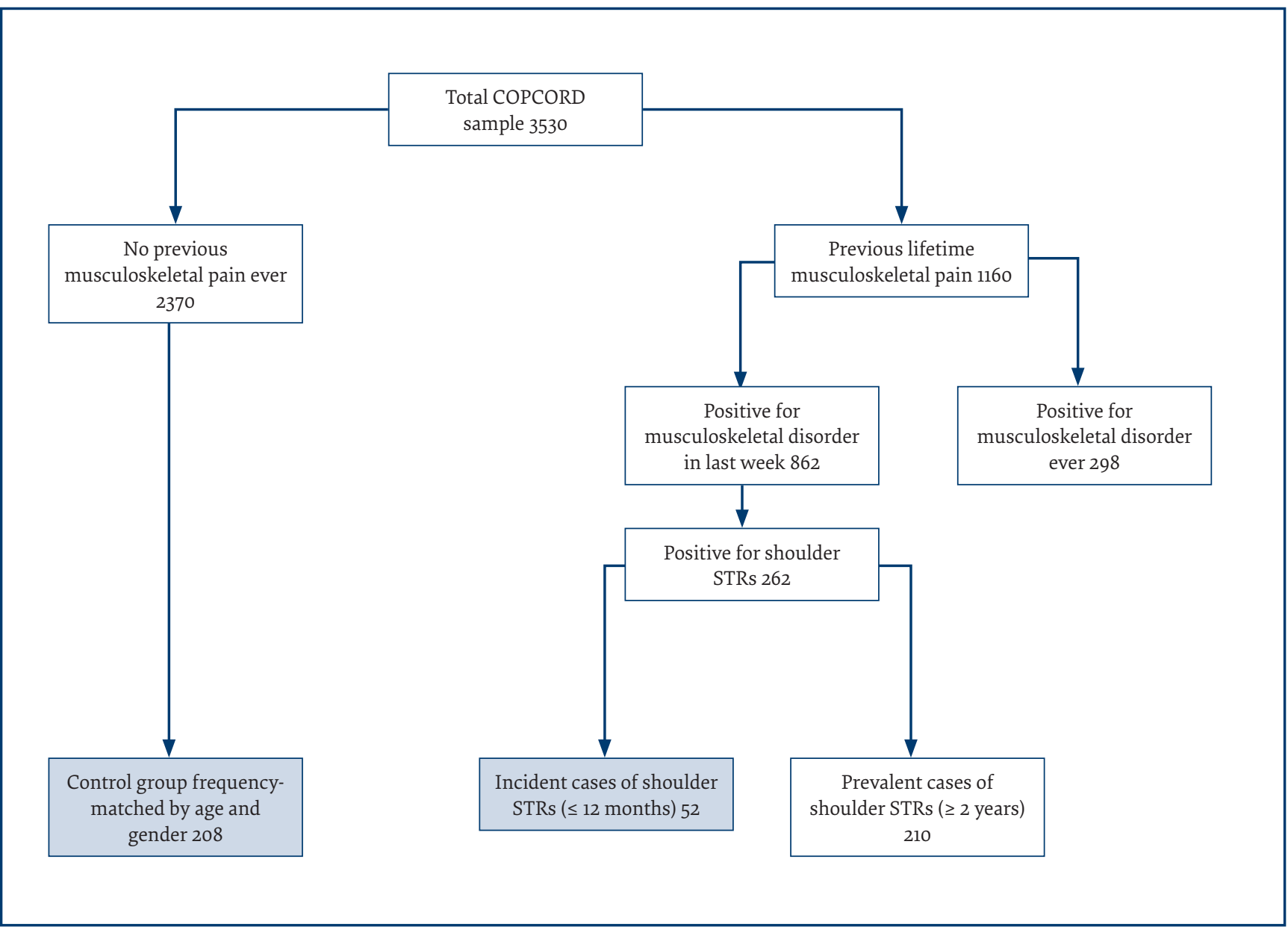

13.13), residing in Bekaa ( $\mathrm{OR}=12.25,95 \% \mathrm{CI}: 4.26-35.21)$ and North (OR $=10.14$, 95\% CI: 4.3-23.89) governorates, complaining of stress-induced sleep difficulty $(\mathrm{OR}=$ 16.13, 95\% CI: 7.14-36.4) and rating personal health status as worse than others ( $O R=20.5,95 \% C I$ : 5.15-81.58) were all significantly associated with increased occurrence of shoulder STRs.

Those working in agriculture and the military had 3.74 greater odds of shoulder STRs compared to those in administrative and manual jobs, but this finding was not statistically significant $(P=0.17)$.

Table 3 shows the final multivariable model. Adjusting for other variables, the highest odds of shoulder STRs were found among those having stress-induced sleep difficulty [adjusted odds ratio (ORadj) 14.6; 95\% CI: 4.23-50.46]; for those living in Bekaa governorate [ORadj 12.72; 95\% CI: 3.1-52.2] and for those engaging in regular physical activity [ORadj 12.57; 95\% CI: 3.58-44.13].

\section{Discussion}

This study is the first attempt to investigate the factors associated with syndromes of STRs affecting shoulder joint among the Lebanese adult population. It is worth noting that incident shoulder STRs cases considered for
Table 1 Baseline characteristics of the study cases (shoulder soft tissue rheumatism), Lebanon, $2009(n=52)$

\begin{tabular}{|c|c|c|}
\hline Characteristic & No. & $\%$ \\
\hline Female & & 67.3 \\
\hline Having difficulty in doing daily activities & 26 & 50 \\
\hline Not able to cope with shoulder problem & 15 & 28.8 \\
\hline $\begin{array}{l}\text { Diagnosed and received treatment for shoulder } \\
\text { problem }\end{array}$ & 30 & 57.7 \\
\hline \multicolumn{3}{|l|}{ Received treatment from $(n=30)$ : } \\
\hline Doctor & 23 & 76.7 \\
\hline Pharmacist & 3 & 10.0 \\
\hline Physiotherapist & 3 & 10.0 \\
\hline Self-treatment & 9 & 30.0 \\
\hline \multicolumn{3}{|l|}{ Diagnosed by doctor as $(n=23)$ : } \\
\hline Rheumatism & 5 & 21.7 \\
\hline Arthritis & 5 & 21.7 \\
\hline Osteoarthritis & 1 & 4.3 \\
\hline \multirow[t]{2}{*}{ Other } & 12 & 52.2 \\
\hline & Mean & SD \\
\hline Age (years) & 38.7 & 14.6 \\
\hline Pain on visual analog scale (range o-10) & 6.5 & 1.9 \\
\hline
\end{tabular}

$S D=$ standard deviation . 
Table 2 Bivariate associations between sociodemographic, behavioural, constitutional and psychosocial risk factors and shoulder soft tissue rheumatism in a population based case-control study, Lebanon, 2009

\begin{tabular}{|c|c|c|c|c|c|}
\hline Variable & $\begin{array}{c}\text { Cases } \\
(n=52) \\
\text { No. }(\%)\end{array}$ & $\begin{array}{c}\text { Controls } \\
(n=208) \\
\text { No. }(\%)\end{array}$ & $\begin{array}{c}\text { Total } \\
\text { No. }(\%)\end{array}$ & $\begin{array}{l}\text { Unadjusted OR } \\
(95 \% \mathrm{CI})\end{array}$ & P-value \\
\hline \multicolumn{6}{|l|}{ Age (years) } \\
\hline $17-39$ & $25(48.1)$ & $100(48.1)$ & $125(48.1)$ & 1.00 & 1.000 \\
\hline$\geq 40$ & $27(51.9)$ & $108(51.9)$ & $135(51.9)$ & $1(0.54-1.84)$ & \\
\hline \multicolumn{6}{|l|}{ Gender } \\
\hline Male & $17(32.7)$ & $68(32.7)$ & $85(32.7)$ & 1.00 & 1.000 \\
\hline Female & $35(67.3)$ & $140(67.3)$ & $175(67.3)$ & $1(0.52-1.91)$ & \\
\hline \multicolumn{6}{|l|}{ Residence } \\
\hline (Beirut/Mount Lebanon) & $10(19.2)$ & $147(70.7)$ & $157(60.4)$ & 1.00 & \\
\hline North & $20(38.5)$ & $29(13.9)$ & $49(18.9)$ & $10.14(4.3-23.89)$ & $<0.001^{*}$ \\
\hline Bekaa & $10(19.2)$ & $12(5.8)$ & $22(8.5)$ & $12.25(4.26-35.21)$ & $<0.001^{*}$ \\
\hline South & $12(23.1)$ & $20(9.6)$ & $32(12.3)$ & $8.82(3.38-23.05)$ & $<0.001^{*}$ \\
\hline \multicolumn{6}{|l|}{ Education level } \\
\hline Low (elementary or below) & & & & 1.00 & \\
\hline Medium (intermediate and high school) & $25(48.1)$ & $119(57.2)$ & $144(55.4)$ & $0.88(0.39-1.99)$ & 0.763 \\
\hline High (university and technical college) & $17(32.7)$ & $47(22.6)$ & $64(24.6)$ & $1.5(0.62-3.68)$ & 0.354 \\
\hline \multicolumn{6}{|l|}{ Income (LL/month) } \\
\hline Low $(<500000)$ & & & & 1.00 & \\
\hline Medium ( $\geq 500000-<1$ million) & $24(46.2)$ & $99(46.8)$ & $123(47.5)$ & $0.28(0.09-0.84)$ & $0.023^{*}$ \\
\hline High ( $\geq 1$ million) & $21(40.4)$ & $100(48.3)$ & $121(46.7)$ & $0.24(0.08-0.73)$ & $0.012^{*}$ \\
\hline \multicolumn{6}{|l|}{ Job } \\
\hline Administrative & & & & 1.00 & 0.539 \\
\hline Manual (tailor, hair dresser, etc) & $4(21.1)$ & $19(20.0)$ & $23(20.2)$ & $1.18(0.35-4.04)$ & 0.170 \\
\hline Agriculture/military & $2(10.5)$ & $3(3.2)$ & $5(4.4)$ & $3.74(0.57-24.63)$ & \\
\hline \multicolumn{6}{|l|}{ Physical activity } \\
\hline Yes & & & & 1.00 & \\
\hline No & $36(81.8)$ & $110(56.4)$ & $146(61.1)$ & $3.48(1.54-7.87)$ & $0.003^{*}$ \\
\hline \multicolumn{6}{|l|}{ Cigarette smoking } \\
\hline No & & & & 1.00 & \\
\hline Yes & $16(40.0)$ & $54(28.7)$ & $70(30.7)$ & $1.65(0.82-3.36)$ & 0.163 \\
\hline \multicolumn{6}{|l|}{ Waterpipe smolking } \\
\hline No & & & & 1.00 & \\
\hline Yes & $11(27.5)$ & $46(24.5)$ & 57 (25.) & $1.17(0.54-2.53)$ & 0.688 \\
\hline \multicolumn{6}{|l|}{ Alcohol } \\
\hline No & & & & 1.00 & \\
\hline Yes & $8(20.0)$ & $44(23.4)$ & $52(22.8)$ & $0.82(0.35-1.9)$ & 0.642 \\
\hline \multicolumn{6}{|l|}{ Body mass index } \\
\hline Normal ( $\leq 24.9$ kg/m2) & & & & 1.00 & \\
\hline Overweight (25.0-29.9 kg/m2) & $18(34.6)$ & $76(36.7)$ & $94(36.3)$ & $0.97(0.53-1.99)$ & 0.968 \\
\hline Obese $(\geq 30 \mathrm{~kg} / \mathrm{m} 2)$ & $9(17.3)$ & $24(11.6)$ & $33(12.7)$ & $1.05(0.66-3.87)$ & 0.293 \\
\hline \multicolumn{6}{|l|}{ Family history } \\
\hline No & & & & 1.00 & \\
\hline Yes & $20(50.0)$ & $26(13.8)$ & $46(20.2)$ & $6.23(2.95-13.13)$ & $<0.001^{*}$ \\
\hline \multicolumn{6}{|l|}{ Stress-induced sleep difficulty } \\
\hline No & & & & 1.00 & \\
\hline Yes & $24(60.0)$ & $16(8.5)$ & $40(17.5)$ & $16.13(7.14-36.4)$ & $<0.001^{*}$ \\
\hline \multicolumn{6}{|c|}{ Self-evaluation for current health status compared to others } \\
\hline Better & & & & 1.00 & \\
\hline Same & $10(25.0)$ & $144(76.6)$ & $154(67.5)$ & $0.24(0.1-0.95)$ & $0.002^{*}$ \\
\hline Worse & $18(45.0)$ & $3(1.6)$ & $21(9.2)$ & $20.5(5.15-81.58)$ & $<0.001^{*}$ \\
\hline
\end{tabular}

* Statistically significant $(\mathrm{P} \leq 0.05)$.

$\mathrm{OR}=$ odds ratio.

CI = confidence interval.

$L L=$ Lebanese lira. 


\begin{tabular}{|c|c|c|}
\hline \multicolumn{3}{|c|}{$\begin{array}{l}\text { Table } 3 \text { Final multivariable logistic regression model for } \\
\text { shoulder soft tissue rheumatism (STR), Lebanon, } 2009\end{array}$} \\
\hline Variable & $\begin{array}{l}\text { Adjusted OR } \\
\text { (95\% CI) }\end{array}$ & $P$-value \\
\hline \multicolumn{3}{|c|}{ Stress-induced sleep difficulty } \\
\hline No & 1.00 & \\
\hline Yes & $14.6(4.23-50.46)$ & $<0.001^{*}$ \\
\hline \multicolumn{3}{|l|}{ Residence area } \\
\hline Beirut/Mount Lebanon & 1.00 & \\
\hline North & $2.34(0.63-8.69)$ & 0.205 \\
\hline Bekaa & $12.72(3.1-52.2)$ & $<0.001^{*}$ \\
\hline \multicolumn{3}{|l|}{ Physical activity } \\
\hline Yes & 1.00 & \\
\hline No & $12.57(3.58-44.13)$ & $<0.001^{*}$ \\
\hline \multicolumn{3}{|c|}{ Family history of shoulder STR } \\
\hline Negative & 1.00 & \\
\hline Positive & $3.34(1.16-9.63)$ & $0.026^{*}$ \\
\hline Goodness-of-fit & $\chi^{2}=50.94$ & 0.476 \\
\hline
\end{tabular}

our study suffered from a high level of pain, were not coping very well and more than half sought medical care and treatment. Chronic shoulder pain causes much distress and more demand on health care services and insurance. The inability to cope with such chronic pain and the high stress level increase the susceptibility to having problems in life, including sleep difficulty, job dissatisfaction and loss, morbidity and depression. This will eventually lead to low quality of life $(3,9,22)$.

The higher representation of females and old age in our study cases is consistent with evidence from other studies. The differences regarding body anthropometrics, hormones, cognitive and coping strategies; and reaction to work stresses render females even more vulnerable, especially in the jobs requiring more masculine body build $(3,12,23)$.

Our results showed that participants from the Bekaa governorate have higher odds of getting shoulder STRs. This could be attributed to the predominance of agricultural activities in this area. It is well-known that agricultural activities incur many risks for shoulder STRs including heavy lifting and hard labour, especially in harvest seasons (24). Such activities are very obvious in our cases, for instance, a number of cases mentioned lifting water barrels. This is consistent with findings from studies on farmers in the United States of America $(25,26)$, female farmers in South Africa (27) and overburdened female farmers in India (28). It was expected to find a similar pattern among residents of the North governorate since most are either involved in agricultural activities or enrolled in the army. At the bivariate level of analysis, there was a statistically significant association between shoulder STRs and having military jobs. A recent study conducted in Brazil echoed this finding (29). However, this association lost significance in the final model. This could be due to the low proportion of army and agricultural activity cases that were included in our study sample.

Familial and cultural backgrounds can greatly influence the predisposition to having a disease and pain perception. Our findings showed that there is a strong genetic predisposition for having shoulder STRs. It has previously been shown that siblings of patients having full-thickness rotator cuff tears, diagnosed by ultrasound, are genetically predisposed to having similar tears (2.42 relative risk) (30). In addition, siblings of patients with shoulder STRs were more likely to experience symptoms (4.65 relative risk) than others (30). Although in the bivariate analysis area of residence was strongly associated with shoulder musculoskeletal disorders, in the multivariable model only residing in the Bekaa was significant. This might be due to the introduction of positive family history in the final model, which might indicate that area of residence is acting as a proxy for consanguineous marriage and family history of shoulder musculoskeletal conditions. The Bekaa region has a high rate of consanguinity in marriage (31).

Even after adjusting for other variables, stressinduced sleep difficulty was significantly associated with having shoulder musculoskeletal disorder. Nevertheless, given the cross-sectional nature of the study, temporality cannot be ascertained. Furthermore, lack of regular physical activity was significantly associated with shoulder pain, which is expected. This is consistent with previous findings that individuals who exercised frequently were able to decrease their shoulder inflicted pain (32).

The current study has some strengths: it is a secondary analysis of a population-based cross-sectional study conducted in Lebanon is 2009 on a nationally representative sample of 3530 participants aged 15 and above. Trained rheumatologists from the American University of Beirut Medical Center confirmed all musculoskeletal disorders by clinical and /or laboratory examination. The inclusion of incident cases was another strength of this study. Selection of cases was done meticulously to ensure that only people complaining of shoulder pain, tenderness and stiffness with duration not exceeding 12 months would be included.

Nevertheless, our study had some limitations. One possible limitation is the cross-sectional nature of the original study that does not account for the natural intermittent course of STRs. A cross-sectional study cannot measure disease incidence because risk or rate require information across a time period, nevertheless, this study is considered a good proxy for longitudinal data and it can be as informative as longitudinal studies with respect to causal hypotheses. Another limitation is neglecting to include important variables such as blood pressure and blood glucose level. These could be helpful in providing an idea about the metabolic profile of the cases and link to the pathogenesis of shoulder STRs. Finally, the small sample size could be a 
limitation, and was in fact reflected in the width of the confidence intervals. However, the selection of 4 controls for each case was made to take this into account, and the results are consistent with evidence from previous studies, indicating that these results are likely unbiased.

\section{Conclusion}

Results from this study showed that vulnerable population groups such as elderly, women and children are dis- proportionately affected by shoulder pain. Studies using more rigorous study designs investigating risk factors for shoulder STRs and how different population groups such as elderly and some working groups are affected are needed to find better solutions to lessen the burden of MSK disorders.

\section{Funding: None.}

Competing interests: None declared.

\section{Facteurs de risque pour les cas incidents de troubles rhumatismaux des tissus mous de l'épaule : étude cas-témoin populationnelle au Liban}

\section{Résumé}

Contexte : Les troubles rhumatismaux des tissus mous sont très courants et ont un impact énorme sur la population générale, les personnes actives et les pratiques de physiothérapie. Pour autant, il n'existe ni définition de cas claire, ni tests objectifs permettant un diagnostic précis à leur sujet, faisant d'eux des troubles négligés avec une charge mal évaluée. L'épaule est l'un des sites les plus fréquents pour les troubles rhumatismaux des tissus mous.

Objectifs : Identifier les facteurs de risque des troubles rhumatismaux des tissus mous de l'épaule parmi des adultes libanais âgés de 15 ans et plus.

Méthodes : Une étude cas-témoin a été conçue sur la base des données du Programme communautaire pour la lutte contre les maladies rhumatismales conduite au Liban en 2009. Les cas ont été définis comme ceux souffrant depuis peu de douleurs, de sensibilité ou de raideur dans l'épaule sur une durée n'excédant pas 12 mois (52 cas). Ils ont été appariés en fréquence sur l'âge et le sexe avec 208 témoins qui n'avaient jamais souffert de douleurs musculo-squelettiques.

Résultats : Le lieu de résidence, l'activité physique, les antécédents familiaux et les troubles du sommeil liés au stress constituaient des facteurs de risque significatifs pour les troubles rhumatismaux des tissus de l'épaule après un ajustement sur la consommation de cigarettes, la nature de la profession et les revenus familiaux mensuels.

Conclusion : Les facteurs prédictifs des troubles rhumatismaux des tissus de l'épaule dans la population libanaise incluaient le lieu géographique, les facteurs psychosociaux, l'activité physique et une prédisposition familiale. Davantage d'études longitudinales sont requises en vue d'établir une séquence temporelle et d'examiner les autres éventuels déterminants, notamment au sein de la population active.

$$
\begin{aligned}
& \text { عو امل الخطر المرتبطة بالاضطر ابات الروماتزمية للأنسجة الرخوة في منطقة الكتف: دراسة حالة سكانية ضابطة في } \\
& \text { لبنان } \\
& \text { محمد جودة، مونيك شعيا، زينب سليم، عحلد عثمان }
\end{aligned}
$$

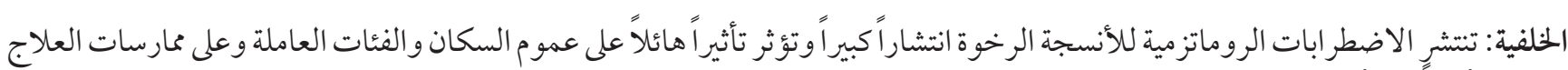

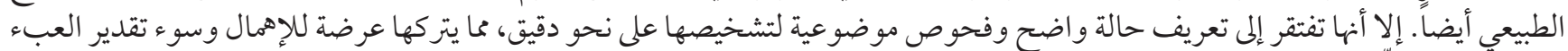

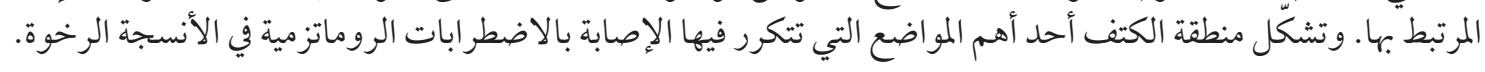

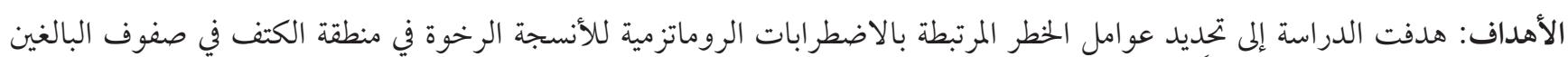

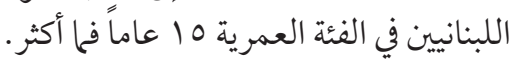

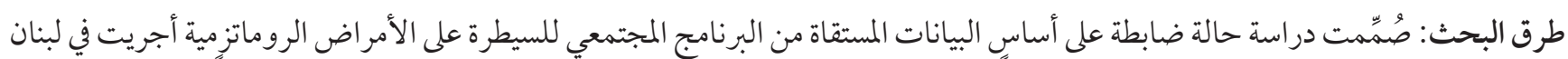

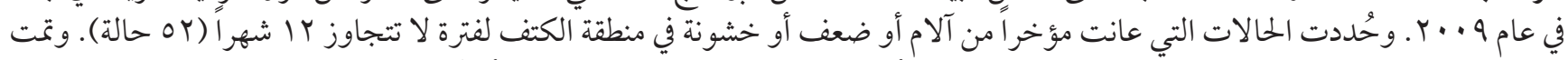

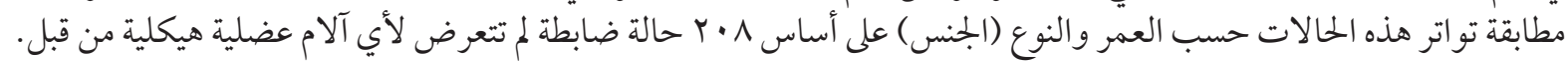

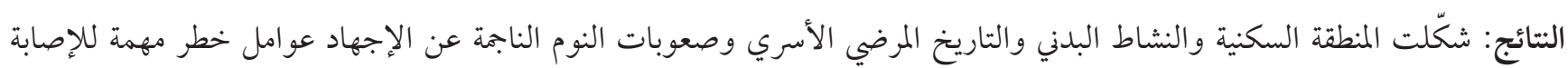

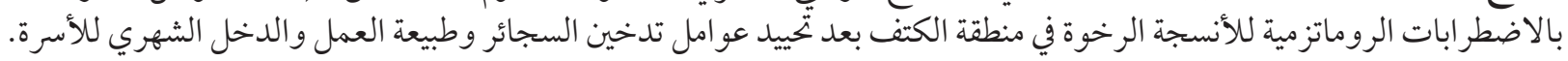

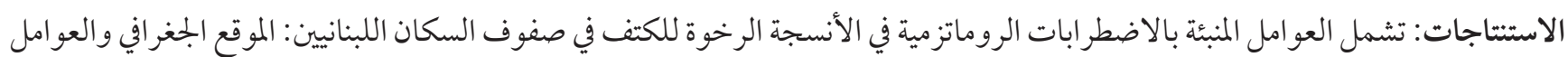

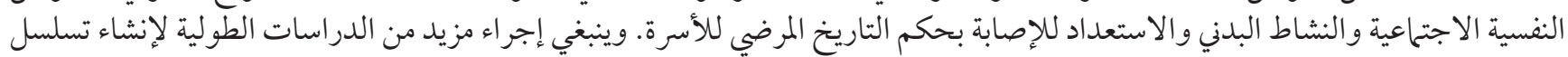

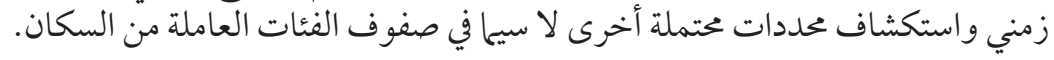




\section{References}

1. Hoy DG, Smith E, Cross M, Sanchez-Riera L, Blyth FM, Buchbinder R, et al. Reflecting on the global burden of musculoskeletal conditions: lessons learnt from the Global Burden of Disease 2010 Study and the next steps forward. Ann Rheum Dis. 2014:annrheumdis-2014-205393. PMID:24914071

2. Dharmanand BG. Approach to a patient with soft tissue rheumatic pain. Indian J Rheumatology. 2014;9:S3-S5.

3. Walker-Bone KE, Palmer KT, Reading I, Cooper C. Soft-tissue rheumatic disorders of the neck and upper limb: prevalence and risk factors. Semin Arthritis Rheum; 2003;33(3):185-203. PMID:14671728

4. Bhattacharya A. Costs of occupational musculoskeletal disorders (MSDs) in the United States. Int J Industrial Ergonomics. 2014;44(3):448-54.

5. Chopra A. Disease burden of rheumatic diseases in India: COPCORD perspective. Indian J Rheumatology. 2015;10(2):70-7.

6. Luime J, Koes B, Hendriksen I, Burdorf A, Verhagen A, Miedema H, et al. Prevalence and incidence of shoulder pain in the general population; a systematic review. Scand Jf Rheumatol. 2004;33(2):73-81. PMID:15163107

7. Chaaya M, Slim ZN, Habib RR, Arayssi T, Dana R, Hamdan O, et al. High burden of rheumatic diseases in Lebanon: a COPCORD study. Int J Rheum Dis. 2012;15(2):136-43. PMID:22462416

8. Natvig B, Picavet HSJ. The epidemiology of soft tissue rheumatism. Best Pract Res Clin Rheumatol. 2002;16(5):777-93.

9. Cho CH, Jung SW, Park JY, Song KS, Yu KI. Is shoulder pain for three months or longer correlated with depression, anxiety, and sleep disturbance? J Shoulder Elbow Surg. 2013;22(2):222-8. PMID:22738644

10. Bergman S. Public health perspective-how to improve the musculoskeletal health of the population. Best Pract Res Clin Rheumatol. 2007;21(1):191-204. PMID:17350552

11. Virta L, Joranger P, Brox JI, Eriksson R. Costs of shoulder pain and resource use in primary health care: a cost-of-illness study in Sweden. BMC Musculoskelet Disord. 2012;13(1):17. PMID:22325050

12. Fillingim RB, King CD, Ribeiro-Dasilva MC, Rahim-Williams B, Riley JL. Sex, gender, and pain: a review of recent clinical and experimental findings. J Pain. 2009;10(5):447-85. PMID:19411059

13. Greenspan JD, Craft RM, LeResche L, Arendt-Nielsen L, Berkley KJ, Fillingim RB, et al. Studying sex and gender differences in pain and analgesia: a consensus report. Pain. 2007;132:S26-S45. PMID:17964077

14. Deere KC, Clinch J, Holliday K, McBeth J, Crawley EM, Sayers A, et al. Obesity is a risk factor for musculoskeletal pain in adolescents: findings from a population-based cohort. Pain. 2012;153(9):1932-8. PMID:22805779

15. Viikari-Juntura E, Shiri R, Solovieva S, Karppinen J, LeinoవArjas P, Varonen H, et al. Risk factors of atherosclerosis and shoulder pain-is there an association? A systematic review. Eur J Pain. 2008;12(4):412-26. PMID:17892959

16. Larsson UE. Influence of weight loss on pain, perceived disability and observed functional limitations in obese women. Int J Obesity. 2004;28(2):269-77.

17. Lane NE. Epidemiology, etiology, and diagnosis of osteoporosis. Am J Obstet Gynecol.. 2006;194(2):S3-S11. PMID:16448873

18. Bodin J, Ha C, Serazin C, Descatha A, Leclerc A, Goldberg M, et al. Effects of individual and work-related factors on incidence of shoulder pain in a large working population. J Occup Health. 2012;54(4):278-88. PMID:22672884

19. Abate M, Vanni D, Pantalone A, Salini V. Cigarette smoking and musculoskeletal disorders. Muscles, Ligaments Tendons J. 2013;3(2):63. PMID:23888288

20. Holth HS, Werpen HK, Zwart J-A, Hagen K. Physical inactivity is associated with chronic musculoskeletal complaints 11 years later: results from the Nord-Trøndelag Health Study. BMC Musculoskelet Disord. 2008;9(1):159. PMID:19046448

21. Hildebrandt V, Bongers P, Dul J, Van Dijk F, Kemper H. The relationship between leisure time, physical activities and musculoskeletal symptoms and disability in worker populations. Int Arch Occup Environ Health. 2000;73(8):507-18. PMID:11100945

22. Linaker CH, Walker-Bone K. Shoulder disorders and occupation. Best Pract Res Clin Rheumatol. 2015;29(3):405-23. PMID:26612238

23. Linton SJ, van Tulder MW. Preventive interventions for back and neck pain problems: what is the evidence? Spine. 2001;26(7):778-87. PMID:11295900

24. Osborne A, Blake C, Fullen BM, Meredith D, Phelan J, McNamara J, et al. Prevalence of musculoskeletal disorders among farmers: a systematic review. Am J Ind Med. 2012;55(2):143-58. PMID:22069159

25. Rosecrance J, Rodgers G, Merlino L. Low back pain and musculoskeletal symptoms among Kansas farmers. Am J Ind Med. 2006;49(7):547-56. PMID:16685722

26. Fethke NB, Merlino LA, Gerr F, Schall MC, Branch CA. Musculoskeletal pain among Midwest farmers and associations with agricultural activities. Am J Ind Med. 2015;58(3):319-30. PMID:25345841

27. Naidoo S, Kromhout H, London L, Naidoo R, Burdorf A. Musculoskeletal pain in women working in smallవscale agriculture in South Africa. Am J Ind Med. 2009;52(3):202-9. PMID:19035594

28. Suthar N, Kaushik V. Musculoskeletal problems among agricultural female workers. Studies on Home and Community Sci. 2013;7(3):145-9. 
29. Junior LM, de Oliveira RW, Gaviraghi J. The prevalence of musculoskeletal pain in military police of Caxias do Sul (RS-Brazil). Physiotherapy. 2015;101:e1053.

30. Harvie P, Ostlere S, Teh J, McNally E, Clipsham K, Burston B, et al. Genetic influences in the aetiology of tears of the rotator cuff sibling risk of a full-thickness tear. J Bone Joint Surg Br. 2004;86(5):696-700. PMID:15274266

31. Kanaan ZM, Mahfouz R, Tamim H. The prevalence of consanguineous marriages in an underserved area in Lebanon and its association with congenital anomalies. Genet Test. 2008;12(3):367-72. PMID:18666858

32. Mattila R, Malmivaara A, Kastarinen M, Kivelä S-L, Nissinen A. Effects of lifestyle intervention on neck, shoulder, elbow and wrist symptoms. Scand J Work Environ Health. 2004:191-8. PMID:15250647 